\title{
Primary total hip arthroplasty in patients with rheumatoid arthritis
}

Accepted: 7 November 2000 / Published online: 22 February 2001 (C) Springer-Verlag 2001 des proviennent non seulement de la méthode de fixation mais aussi d'une mauvaise qualité osseuse.

\section{Introduction}

Total hip arthroplasty (THA) is perhaps one of the most successful operations for patients with rheumatoid arthritis (RA) in terms of pain relief, functional gain, and patient satisfaction. Despite the lower activity level and the lower body weight of these patients, the literature has documented the relatively inferior long-term results of cemented THA among patients with RA $[3,5,15,17$, $18,20,21,24]$. Recently noncemented prostheses have also been used in RA patients, but there are only a few reports describing the short-term results $[9,13,14,16]$. We reviewed the results of primary THAs performed on a group of RA patients. Both cemented and noncemented prostheses were used. The age at operation and the preoperative hip score were comparable between the cemented and the noncemented groups. de 10,8 années. Deux infections profondes ont nécessité l'ablation de la prothèse. Trois composants cotyloidiens cimentés et un composant fémoral cimenté ont été révisé à cause d'un descellement aseptique. Un composant cotyloidien montre un descellement radiographique. Un insert de polyéthylène a été remplacé à cause d'une usure notable. Les composants fémoraux cimentés et noncimentés ont la capacité de fournir un résultat acceptable dans le cas d'une polyarthrite rhumato. Les résultats relativement inférieurs des prothèses totales chez ces mala-

\footnotetext{
W.M. Tang $(\bowtie) \cdot$ K.Y. Chiu

Division of Joint Replacement Surgery,

Department of Orthopaedic Surgery,

The University of Hong Kong

e-mail:wmtanga@hkucc.hku.hk

Tel.: +852-2855-4654, Fax: +852-2817-4392

W.M. Tang

Department of Orthopaedic Surgery,

Queen Mary Hospital, 102 Pokfulam Road,

Pokfulam, Hong Kong SAR, China
}

\section{Materials and methods}

Between 1980 and 1995, we performed 28 THAs in 20 patients who fulfilled the diagnostic criteria for rheumatoid arthritis [1]. Eight patients had bilateral THA (Table 1). Three of them had bilateral cemented THA, one had bilateral noncemented THA and four patients had noncemented THA on one side and cemented THA on the other. Seventeen noncemented and 11 cemented prostheses were used. The noncemented prostheses included the porous coated anatomic (PCA) (Howmedica, Rutherford, New Jersey), Omnifit (Osteonics, Allendale, NJ), and the anatomic medullary locking (AML) (Depuy, Warsaw, Indiana) prostheses. All cemented prostheses were Charnley low-friction arthroplasty (Thackray, Leeds, UK) performed using first generation cementing technique. The posterior approach was adopted throughout. Only one dose of antibiotic was given prophylactically at the time of induction.

The average age at the time of operation for those who received cemented prostheses was 41.5 years (SD 16.5, range 17.4-68.0) and for those who received noncemented prostheses 42.5 years (SD 16.0, range 19.7-77.4). The bone quality of the proximal femur at operation was documented according to Dorr's 
Table 1 Patient data

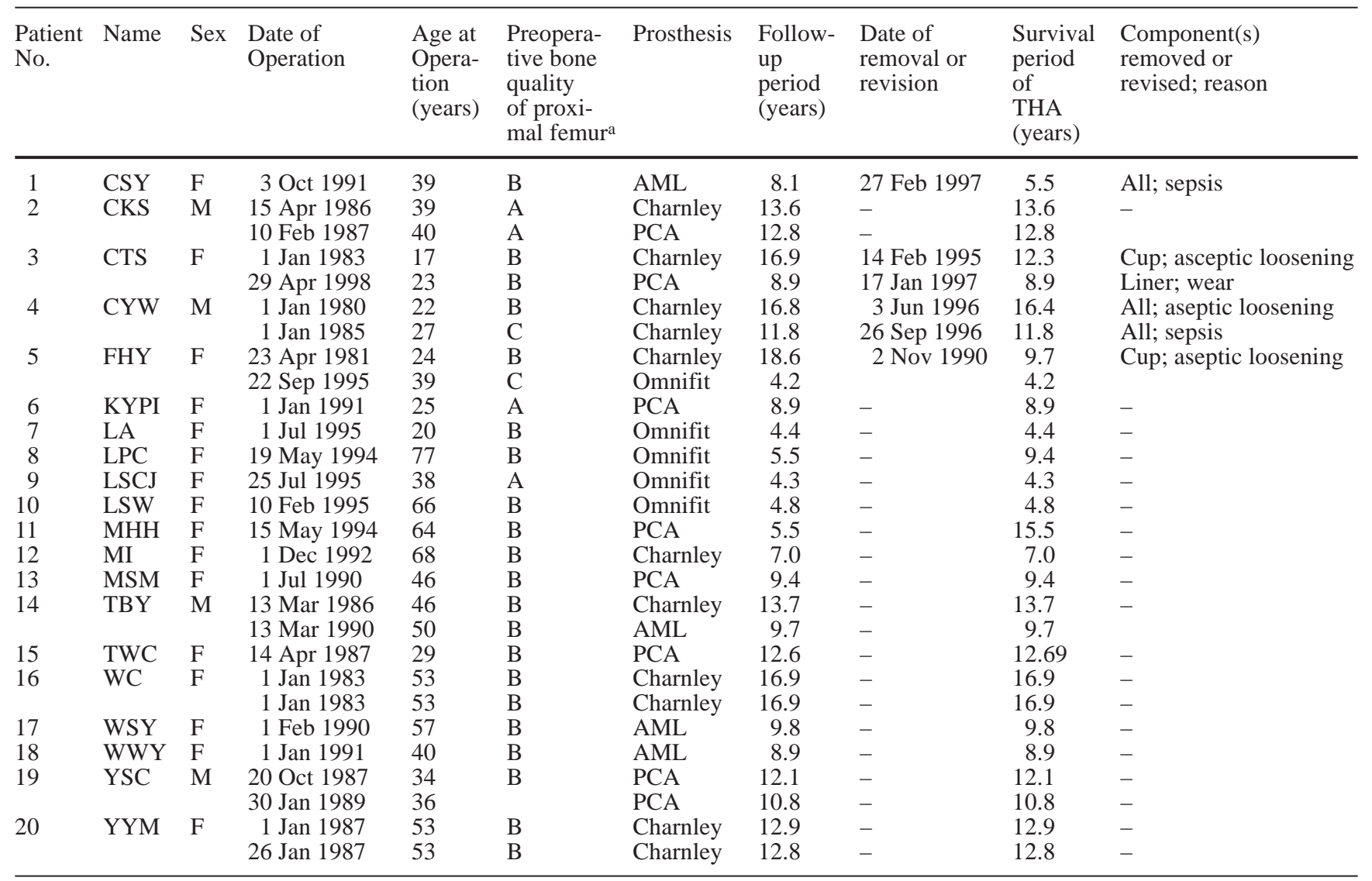

a Dorr's classification [7]

classification [7]. All patients were regularly followed up in our outpatient clinic with annual radiological examination of the hips. The average follow-up period was 14.3 years (SD 3.3, range 7.0-18.6) for the cemented group and 8.4 years (SD 3.1, range 4.2-12.8) for the noncemented group.

Clinical assessment in terms of pain, function, deformities, and range of movement was based on Harris's evaluation system [11]. Radiological assessment during each follow-up session included a standing anteroposterior radiograph of the pelvis with the X-ray beam centered at the pubic symphysis, and a lateral radiograph of the operated hip joint. Demarcation of the acetabular components was recorded using the zonal system described by DeLee and Charnley [6]. The zonal system described by Gruen et al. [10] was adopted to record the site of stem demarcation. Radiological loosening of the acetabular component was defined as Hodgkinson type 3 or 4 demarcation of the cup [12]. Femoral component loosening was defined as more than $5 \mathrm{~mm}$ of subsidence on plain radiograph, or a fracture of the cement or the stem, or a complete radiolucent line more than $2 \mathrm{~mm}$ in thickness [15].

\section{Results}

All patients had substantial clinical improvement in terms of pain, function, and range of motion. The average preoperative hip score was 25.3 , improved to 88.9 postoperatively. Preoperatively twenty hips had severe pain, and 8 hips moderate pain. Postoperatively 19 hips were entirely pain-free and 9 hips had only occasional discomfort. No significant difference in the preoperative hip score was found between the cemented and noncemented groups $(P>0.7)$.

Four THAs in three patients were revised due to aseptic loosening (Table 1). Of the cemented THAs, two required revision for the acetabular component only and another one required revision of both the cup and the stem. One more cemented acetabular component has loosened radiologically in an asymptomatic patient. Two more femoral components had subsided $3 \mathrm{~mm}$ on the most recent radiographs. For the noncemented THAs, only one polyethylene liner was revised due to significant wear. On the same patient, osteolysis in zone I of the stem was evident on the radiograph at the time the liner was revised. The stem was, however, shown to be well fixed and therefore not revised during the operation. One more PCA stem displaced a nonprogressive subsidence of $4 \mathrm{~mm}$. Another stem subsided $3 \mathrm{~mm} 3$ years after the operation and has shown no further migration since then. Three cups had a $1 \mathrm{~mm}$ radiolucent line at zone 1.

We encountered two deep infections in two patients (Table 1), and both were late infection caused by methicillin-resistant Staphylococcus aureus. Other complications included two intraoperative fissures at the femoral calcar managed by cerclage wiring. No dislocation was recorded in any of our patients. 
Table 2 Summary of reports on cemented THAs in RA patients

\begin{tabular}{|c|c|c|c|c|c|c|c|}
\hline \multirow[t]{2}{*}{ Authors (year) } & \multirow{2}{*}{$\begin{array}{l}\text { No. of } \\
\text { THA/no. } \\
\text { of RA } \\
\text { patients }\end{array}$} & \multirow{2}{*}{$\begin{array}{l}\text { Mean } \\
\text { age at } \\
\text { operation } \\
\text { (years) }\end{array}$} & \multirow{2}{*}{$\begin{array}{l}\text { Mean } \\
\text { follow- } \\
\text { up } \\
\text { (years) }\end{array}$} & \multicolumn{4}{|c|}{ Important findings } \\
\hline & & & & $\begin{array}{l}\text { No. of cups } \\
\text { revised for } \\
\text { aseptic } \\
\text { loosening } \\
(\%)\end{array}$ & $\begin{array}{l}\text { No. of stems } \\
\text { revised for } \\
\text { aseptic } \\
\text { loosening } \\
(\%)\end{array}$ & $\begin{array}{l}\text { No. of } \\
\text { loosened cups: } \\
\text { revised+ } \\
\text { radiological } \\
(\%)\end{array}$ & $\begin{array}{l}\text { No. of } \\
\text { loosened stems: } \\
\text { revised+ } \\
\text { radiological } \\
(\%)\end{array}$ \\
\hline Poss (1984) & $138 / 98$ & 58.0 & 7.0 & $0(0 \%)$ & $5(3.6 \%)$ & $107(77.5 \%)$ & $5(3.6 \%)$ \\
\hline Unger (1987) & $83 / 51$ & 39.9 & 12.1 & $6(7.2 \%)$ & $11(13.3 \%)$ & $6(7.2 \%)$ & $11(13.3 \%)$ \\
\hline Severt (1991) & $75 / 53$ & 49.9 & 7.4 & $4(5.3 \%)$ & $1(1.3 \%)$ & $11(14.6 \%)$ & $5(6.7 \%)$ \\
\hline Chmell (1997) & $66 / 39$ & 19.9 & 15.1 & $23(34.8 \%)$ & $12(18.1 \%)$ & $29(43.9 \%)$ & $12(18.1 \%)$ \\
\hline Creighton (1998) & $103 / 73$ & 62.0 & 14.6 & $2(1.9 \%)$ & $2(1.9 \%)$ & $10(9.7 \%)$ & $4(3.9 \%)$ \\
\hline Lehtimaki (1999) & $1553 / 1086$ & 53.1 & $\begin{array}{l}\text { Up to } \\
20 \text { years }\end{array}$ & \multicolumn{4}{|c|}{$\begin{array}{l}\text { Survival probability of cups and stems at } 15 \text { years: } 87.1 \% \text { and } 89.9 \% \text {, } \\
\text { respectively }\end{array}$} \\
\hline Tang (present series) & $11 / 8$ & 41.5 & 14.3 & $3(27.3 \%)$ & $1(9.0 \%)$ & $4(36.3 \%)$ & $1(9.0 \%)$ \\
\hline
\end{tabular}

Table 3 Summary of reports on noncemented THAs in RA patients

\begin{tabular}{|c|c|c|c|c|c|c|c|}
\hline \multirow[t]{2}{*}{ Authors (year) } & \multirow{2}{*}{$\begin{array}{l}\text { No. of } \\
\text { THA/no. } \\
\text { of RA } \\
\text { patients }\end{array}$} & \multirow{2}{*}{$\begin{array}{l}\text { Mean } \\
\text { age at } \\
\text { operation } \\
\text { (years) }\end{array}$} & \multirow{2}{*}{$\begin{array}{l}\text { Mean } \\
\text { follow- } \\
\text { up } \\
\text { (years) }\end{array}$} & \multicolumn{4}{|c|}{ Important findings } \\
\hline & & & & $\begin{array}{l}\text { No. of cups } \\
\text { revised for } \\
\text { aseptic } \\
\text { loosening } \\
(\%)\end{array}$ & $\begin{array}{l}\text { No. of stems } \\
\text { revised for } \\
\text { aseptic } \\
\text { loosening } \\
(\%)\end{array}$ & $\begin{array}{l}\text { No. of } \\
\text { loosened cups: } \\
\text { revised+ } \\
\text { radiological } \\
(\%)\end{array}$ & $\begin{array}{l}\text { No. of } \\
\text { loosened stems: } \\
\text { revised+ } \\
\text { radiological } \\
(\%)\end{array}$ \\
\hline Lachiewicz (1994) & $35 / 25$ & 41.0 & 4.5 & $0(0 \%)$ & $0(0 \%)$ & $1(2.9 \%)$ & $0(0 \%)$ \\
\hline Kumar (1998) & $25 / 16$ & 24.9 & 4.5 & $3(11.1 \%)$ & $1(3.7 \%)$ & $3(11.1 \%)$ & $1(3.7 \%)$ \\
\hline Araujo (1998) & $33 / 32$ & 51.4 & 5.0 & $0(0 \%)$ & $0(0 \%)$ & $0(0 \%)$ & $0(0 \%)$ \\
\hline Loehr (1999) & $21 / 15$ & 53.0 & 3.3 & $0(0 \%)$ & $0(/ 0 \%)$ & $0(0 \%)$ & $5(23.8 \%)$ \\
\hline Tang (present series) & $17 / 16$ & 42.5 & 8.4 & $1(5.9 \%)$ & $0(0 \%)$ & $1(5.9 \%)$ & $0(0 \%)$ \\
\hline
\end{tabular}

\section{Discussion}

Choice of implant fixation in THA remains a controversial subject $[3,14,20,24]$, particularly in patients with RA. Although they are usually younger than those with osteoarthritis, the bone stock of RA patients are usually poorer because of the disease activity as well as the medical treatment, i.e., the use of nonsteroidal antiinflammatory drugs and steroids $[3,15,18]$. The results of cemented prostheses in RA patients are generally believed to be inferior when compared to those done for osteoarthritis $[3,5,15,17,18,20,21,24]$, despite the lower activity level and the lower body weight of the patients. Recently the use of noncemented hip prostheses has been extended to RA patients, and the early results reported so far are quite promising $[9,13,14,16]$. However, the ability of bone in-growth onto the noncemented implants and thus the long-term results of these implants in RA patients has been severely questioned [13]. Therefore, the THA fixation method used in RA patients is an even more pertinent issue than in other situations. However, all the reported series are concentrated on one type of implant and there is no comparative study to address this controversy.

As in other inflammatory arthritic conditions involving young patients $[21,23]$, cemented prosthesis among
RA patients presented more failure due to aseptic loosening of the acetabular component than of the femoral (Table 2) $[3,5,15,18,19,20,24]$. The Charnley prosthesis in our series demonstrated a pattern similar to other series. At an average follow-up of 14.3 years, only one out of 11 Charnley stems was revised for aseptic loosening. On the acetabular side, we had, however, four cups with mechanical failure. Poss et al. [18] attributed the acetabular component loosening to the failure of restoring a normal acetabular position in hips with acetabular protrusion. Severt et al. suggested that a higher loosening rate of the cemented cups was related to a younger age at the time of implantation [20]. Creighton et al., however, concluded that radiographic loosening of the acetabular component was significantly associated with a younger age at operation, but not with the inability to restore the hip center in acetabular protrusion [5]. In our series, the patients who had their cemented prosthesis revised were 25 years younger at the time of the primary surgery.

Noncemented implants have only recently been used in RA patients. The short-term results of HA-coated prostheses [9] and porous-coated prostheses [14] are promising. However, none of the reports so far has documented more than 5 years' follow-up of noncemented prostheses (Table 3) $[9,13,14,16]$. The noncemented 
prostheses did well in our patients, both on the acetabular as well as on the femoral side. The porous-coated AML and PCA prostheses in our series have been followed up for an average of 9.1 and 10.5 years, respectively, and only one non-progressive subsidence of a PCA stem was observed. One further PCA polyethylene liner was revised because of significant wear.

Although the cemented and noncemented groups in our series were comparable in terms of age at operation and the preoperative hip score, we did not attempt to answer the question of whether one fixation method is better than the other in THA among RA patients. Obviously our series is small when compared to reports from tertiary referral centres. Unlike knee involvement, severe hip arthritis is generally less common among RA patients [4, $8,22]$. However, our study suggested that on the femoral side, both cemented and noncemented implants might give RA patients a reasonable length of longevity. One might favor the use of the noncemented femoral stem because it is generally less technically demanding and more flexible due to its modularity, although modularity is now also available in cemented femoral components. On the acetabular side, we favor the use of a noncemented cup because of the lower rate of aseptic loosening. Noncemented acetabular components also allow changing the polyethylene liner without revising the whole cup.

It helps to remember that all arthroplasties do fail with time $[2,15]$. Nevertheless, a great deal of emphasis has been placed on the choice of implant fixation. The longevity of THA among RA patients also depends on the quality of bone supporting the prostheses. RA is a bone-loss disease, and the continuous bone remodeling may jeopardize the bonding at the bone-cement interface, even though the initial cement penetration into the bone was good. Drugs used for treatment also affect bone in-growth onto noncemented implants. Therefore, unless the bone-loss situation can be reversed, the results of THA among RA patients will probably remain inferior.

\section{References}

1. Arnett FC (1989) Revised criteria for the classification of rheumatoid arthritis. Bull Rheum Dis 38:1-6

2. Charnley J (1961) Arthroplasty of the hip: a new operation. Lancet 1:1129

3. Chmell MJ, Scott RD, Thomas WH, Sledge CB (1997) Total hip arthroplasty with cement for juvenile rheumatoid arthritis. Results at a minimum of ten years in patients less than thirty years old. J Bone Joint Surg Am 79:44-52

4. Coventry MB, Beckenbaugh RD, Nolan DR, Ilstrup DM (1974) 2,012 total hip arthroplasties. A study of postoperative course and early complications. J Bone Joint Surg Am 56: 273-284
5. Creighton MG, Callaghan JJ, Olejniczak JP, Johnston RC (1998) Total hip arthroplasty with cement in patients who have rheumatoid arthritis. A minimum ten-year follow-up study. J Bone Joint Surg Am 80:1439-1446

6. DeLee JG, Charnley J (1976) Radiological demarcation of cemented sockets in total hip replacement. Clin Orthop 121:20 32

7. Dorr LD (1986) Total hip replacement using APR system. Techniques Orthopaed 3:22

8. Dunbar RP, Alexiades MM (1998) Decision making in rheumatoid arthritis. Determining surgical priorities. Rheum Dis Clin North Am 24:35-54

9. Garcia Araujo C, Fernandez Gonzalez J, Tonino A (1998) Rheumatoid arthritis and hydroxyapatite-coated hip prostheses: five-year results. International ABG Study Group. J Arthroplasty 13:660-667

10. Gruen TA, McNeice GM, Amstutz HC (1979) "Modes of failure" of cemented stem-type femoral components: a radiographic analysis of loosening. Clin Orthop 141:17-27

11. Harris WH (1969) Traumatic arthritis of the hip after dislocation and acetabular fractures: treatment by mold arthroplasty. An end-result study using a new method of result evaluation. J Bone Joint Surg Am 51:737-755

12. Hodgkinson JP, Shelley P, Wroblewski BM (1988) The correlation between the roentgenographic appearance and operative findings at the bone-cement junction of the socket in Charnley low friction arthroplasties. Clin Orthop 228:105-109

13. Kumar MN, Swann M (1998) Uncemented total hip arthroplasty in young patients with juvenile chronic arthritis. Ann R Coll Surg Engl 80:203-209

14. Lachiewicz PF (1994) Porous-coated total hip arthroplasty in rheumatoid arthritis. J Arthroplasty 9:9-15

15. Lehtimaki MY, Kautiainen H, Lehto MU, Hamalainen MM (1999) Charnley low-friction arthroplasty in rheumatoid arthritis. A survival study up to 20 years. J Arthroplasty 14:651-661

16. Loehr JF, Munzinger U, Tibesku C (1999) Uncemented total hip arthroplasty in patients with rheumatoid arthritis. Clin Orthop 366:31-38

17. Onsten I, Besjakov J, Carlsson AS (1994) Improved radiographic survival of the Charnley prosthesis in rheumatoid arthritis and osteoarthritis. Results of new versus old operative techniques in 402 hips. J Arthroplasty 9:3-8

18. Poss R, Maloney JP, Ewald FC, Thomas WH, Batte NJ, Hartness C, Sledge CB (1984) Six- to 11-year results of total hip arthroplasty in rheumatoid arthritis. Clin Orthop 182:109-116

19. Ranawat CS, Dorr LD, Inglis AE (1980) Total hip arthroplasty in protrusio acetabuli of rheumatoid arthritis. J Bone Joint Surg Am 62:1059-1065

20. Severt R, Wood R, Cracchiolo A 3d, Amstutz HC (1991) Long-term follow-up of cemented total hip arthroplasty in rheumatoid arthritis. Clin Orthop 265:137-145

21. Sochart DH, Porter ML (1997) Long-term results of total hip replacement in young patients who had ankylosing spondylitis. Eighteen to thirty-year results with survivorship analysis. J Bone Joint Surg Am 79:1181-1189

22. Susman MH, Clayton ML (1992) Management of the rheumatoid hip. In: Clayton ML, Smyth CJ (eds) Surgery for rheumatoid arthritis. Churchill Livingstone, New York, pp 231

23. Tang WM, Chiu KY (2000) Primary total hip arthroplasty in patients with ankylosing spondylitis. J Arthroplasty 15:52-58

24. Unger AS, Inglis AE, Ranawat CS, Johanson NA (1987) Total hip arthroplasty in rheumatoid arthritis. A long-term follow-up study. J Arthroplasty 2:191-197 